\title{
Innovation and Export Competitiveness: Evidence from Georgia Firms
}

\author{
David Sikharulidze
}

Doctorate in Economics, Associate professor, Ivane Javakhishvili Tbilisi State University

Vasil Kikutadze

Doctorate in Economics, Associate professor, Ivane Javakhishvili Tbilisi State University

\begin{abstract}
Innovation has long been considered an important factor for creating and maintaining the competitiveness of nations and firms. Consequently, we examine the effect of innovation on export intensity using the Enterprise Surveys from World Bank Group for Georgian firms. Results evolves that the introduction of innovations, and in particular product innovations, is an important driver of export intensity. This study is based on an analysis of research done among 360 firms from Georgia. Firms that intensively involved in the innovation process record the highest export intensity and the magnitude of the impact of innovation on export is sizeable.
\end{abstract}

Keywords: Innovation; Technological progress, Export competetvness, Productivity

\section{Introduction}

Rapid teqnological changes and incresed global process have radicaly changed the contecst for economic develpment. These changes offer development countries broad prospects both productivity growth and acceess to resoursec and new market.

From 1990 market liberalization of global wave has produced interrelated world economy that leads unprecedented level of business activities and current structural changes. Most government of development world has considered science and technology as vital factor for economic growth and development. It has started the development of knowledge intensive economy. It has been made steps toward the opening market, trade liberalization, attracting foreign direct investment, infrastructure development, industrial research development, improvement of higher education system.

In the 21st century, economies are becoming more knowledge-based, with innovation increasingly the driver of national competitiveness, development, and long-term economic growth.

At the firm level, innovation is the transformation of ideas into new products, services, and production processes-leads to more efficient use of resources, creating sustainable competitive advantages. Their vital role was also noted by M. Porter, who claims that companies reach a competitive advantage as a result of innovative procedures. (Porter, 1980).

It is so widely recognized that innovation is a key driver of economic growth. Innovation has long been considered an important factor for creating and maintaining the competitiveness of nations and firms. The relationship between innovation and exporting has been investigated in many countries. However, there is a few of research in Georgia with respect to this issue.

The development of export activities is a first step in the international growth strategy of firms. For firms based in small, open markets like Georgia, expanding export activities and broadening the geographic scope of export activities is a necessity to continue growth.

This paper analyzes the effect of different types of innovation activities on the export competitiveness of Georgian firms.

Georgia has great potential in terms of development and increased competitiveness-potential which could be achieved by overcoming the barriers which currently hinder the growth of competition and by taking into consideration the country's 
current potential for prospective development. The high rates of economic growth which would benefit the wider population will be achieved by competitive private sector.

On average, the Georgian economy grew by 6 percent annually between 2004 and 2016 . This rate was the result of a wave of reforms aimed at liberalizing the country's economy, but these reforms were not, however, sufficient to increase overall productivity along with private sector competitiveness, and were therefore unable to stimulate long-term economic growth. Goods produced in Georgia score low in added value. At this stage, only the processing industry is relatively developed. This is directly linked to the country's natural resources and local agricultural production. The major reason for these patterns is the low level of technological development and innovation, which, at the same time, causes irrational use of natural resources and jeopardizes the country's natural wealth.

Both government and private sector spending on research and development remain low, which is reflected in various international evaluations and ratings: the 2016 edition of the Global Innovation Index (GII) (GII., 2016) ranks Georgia 64 ${ }^{\text {th }}$, the 2015 edition of the Innovations Capacity Index (ICl) ranks Georgia 73th (out of 131 countries), and the 2017 edition of the World Economic Forum's (World Economic Forum., 2017) "Global Competitiveness Index" (GCl) ranks Georgia in the following positions (out of 138 countries surveyed):

- Capacity for innovation $-105^{\text {th }}$.

- Company spending on R\&D - 123th.

Both Georgia's access to the latest technologies and overall level of technological development

remain low: according to the $\mathrm{GCl}$, Georgia holds the following positions:

- Availability of latest technologies- $111^{\text {th }}$.

- Firm-level technology absorption-111 $11^{\text {th }}$.

Levels of protection of intellectual property - a major factor in the implementation of innovations - are also unsatisfactory: Georgia currently holds the $99^{\text {th }}$ place in terms of protection of intellectual property.

Accordingly, this paper analyzes the effect of different types of innovation activities on the export competitiveness of Georgian firms. We examine the relationship between product and process innovations and the level of exports (export intensity). We draw on firm-level data from the Enterprise surveys from World Bank Group for Georgia in the years 2013 (World Bank., 2013). These surveys contain information on the value of exports of both innovating and non-innovating firms. The analyses control for other firm characteristics such as firm size, labor productivity, capital intensity.

\section{Literature Review}

Increasing globalization pushes and pulls companies and economies to raise their engagement with international markets to sustain innovation and growth. Small open economies, which by definition lacks the high levels of domestic demand and scale available to larger countries, must consider how their firms and economy can meet the challenges of international competitiveness. Innovation has been regarded for a long time as having key significance for economic growth, as well as for the development and welfare of communities. Relationship between export and innovation has been studied in many countries.

Increasing the export competitiveness is the early stage of internationalization in terms of expansion of global markets. For small economies, like Georgia the enhancement of export activities and expansion geographical spaces is crucial for constant growth. The important determinant of successful export is investment in technology that leads the growth of labour productivity, whilst the introduction of innovative product is often associated to the decision for export. (Cassiman, 2007). (Becker, 2007). Thus R\&D and innovation that leads the introduction new products or improvement of firm's production line play important role in strengthening the export market position.

According to the international economy theory, product innovation plays important role for trade in the open economic growth model. There are differences between exogenous and endogenous model of innovation and export competitiveness.

In the neo-classical model of international trade, factor endowments are the key determinants of trade in which firm's competitive advantage are based on factor endowments. To account for technological change, various neo-technological models of international trade have been postulated (Krugman P. , 1979), (Posner M. , 1961). According to ,technology- 
based" models competitive advantage derives from the quality of firm's products or services. Neo-endowment models concentrate on specialization and thus competitive advantage on the basis of factor endowments, such as materials, skilled/unskilled labour, capital and technology (Davis, 1995); while neo-technology models (Greenhalgh, 1994) are an extension of conventional technology-based models based on, for example, product life cycle theory (Vernon, 1966; (Krugman P. , 1979) (Dollar, 1986) and the technology-gap theory of trade (Posner, 1961). More recent macroeconomic models (e.g., Grossman and Helpman, 1995) allow firms to improve the quality of their products, which shifts outward a country's export demand curve. Both of these imply a positive link between R\&D or innovation and exporting.

By contrast, endogenous growth models in the tradition of Grossman and Helpman recognize the possibility of causality running from exporting to R\&D and innovation. Such endogenous growth models (Romer, 1990); (Grossman and Helpman, 1991); (Young, 1991); (Hobday, 1995) cover the need for firms to innovate to meet stronger competition/different standards in foreign markets, they allow for a 'learning-by-exporting' effect and they allow for economies of scale and thus firms to cover the large fixed costs of undertaking R\&D (and innovating).

The channels for this are threefold. First, the stronger competition in foreign markets forces firms to invest in R\&D in order to improve both products and processes and thus remain competitive. Second, there is the possibility of ,learning by exporting" principally involving being exposed to superior foreign knowledge and technology which also helps to boost the productivity of exporting firms (Grossman and Helpman 1991a). Finally, scale effect may be important. Exporting extends the market over which margins may be earned, and since R\&D costs are largely fixed, such investments may be recouped over a larger sales volume. This aids productivity, and provides greater incentives to invest in R\&D and innovation.

Empirical studies at the firm level provide positive relationship R\&D and exports. Various empirical studies have emphasized the role of technology and innovation as one of the major factors contributing to facilitating entry into global markets, and thereafter maintaining competitiveness and boosting export performance. (Kumar N. a., 1994) , (Fagerberg J. , 1996). There are several studies which shows positive relationship between R\&D and export (Kumar N. a., 1994), (Fagerberg J. , 1996). Lefebvre (Lefebvre, 1998) studied small firms in Canada and found that R\&D-related capabilities such as a strong scientific and technical workforce, collaborative R\&D and an R\&D strategy aimed at launching new products, had favorable impact on their export performance. Melitz suggested theoretical model that most productive firms are mostly likely to start exporting activities. The higher productivity of exporting firms is often related to firm-level technological advantages, due to R\&D investments and the introduction of product and process innovations. The higher productivity of exporting firms is often related to firm-level technological advantages, due to R\&D investments and the introduction of product and process innovations. Since innovation is considered as main factor for productivity, larger number of empirical studies have examined the relationship between exports and various input and output measures of innovation and technological capabilities. One of the e focusing on firms' R\&D expenditures or investments in new capital equipment (embodied technological change) has confirmed a strongly positive relationship. (Hirsch \& Bijaoui., 1985) (Belderbos, 1998). Sterlacchini (Sterlacchini., 1999) states that in investment activities in development of product design and pre-production development efforts lead to export success.

\section{Data and Variables}

We analyze the relationship between exporting and innovation by drawing on the Enterprise Surveys from World Bank Group for Georgia. This survey covers the year 2013. (360 firms);

Enterprise Surveys identifies firms as innovative if at least one out of four criteria is met: the firm (a) has launched a new or improved product on the market, (b) has realized new or improved processes, (c) was involved in innovation activities that are still ongoing, or (d) was involved in innovation activities that have been untimely aborted. In each survey, a question is included the export intensity of the firm.

The sample for Georgia ES was selected using stratified random sampling. Three levels of stratification were used in this country: industry, establishment size, and region.

Industry stratification was designed in the way that follows: the universe was stratified into one manufacturing industry, and two service industries (retail, and other services).

Size stratification was defined following the standardized definition for the rollout: small ( 5 to 19 employees), medium (20 to 99 employees), and large (more than 99 employees). For stratification purposes, the number of employees was defined 
on the basis of reported permanent full-time workers. This seems to be an appropriate definition of the labor force since seasonal/casual/part-time employment is not common practice, apart from the construction and agriculture sectors which are not included in the survey.

Regional stratification was defined in 6 regions (city and the surrounding business area) throughout Georgia. Database from the National Statistical Office of Georgia was used as the frame for the selection of a sample with the aim of obtaining interviews at 360 establishments with five or more employees. Given the impact that non-eligible units included in the sample universe may have on the results, adjustments may be needed when computing the appropriate weights for individual observations. The percentage of confirmed non-eligible units as a proportion of the total number of sampled establishments contacted for the survey was $26.4 \%$ (341 out of 1,290 establishments).

\section{Results}

The results of the present study suggest that the exporting companies in Georgia are situated mainly in the urban areas with $40,91 \%$ localized in the capital city of Georgia. The primary reason for the enterprises running their business activities to initiate exporting was to acquire new markets, which should in a short or longer time span result in maximizing their profits. The vast majority of the studied firms, both exporters and non-exporters, have been running their activities for at least six years.

The most numerous group of exporters among manufacturing companies offers products such as food, $(40,91 \%)$, Chemicals $(9,09 \%)$, non metallic mineral products $(9,09 \%)$, furniture $(9,09 \%)$, Retail $(9,09 \%)$, construction $(4,55 \%)$, Other transport equipment $(4,55 \%)$, Wholesale $(4,55 \%)$.

\section{Direct exports as a $\%$ of total annual sales by region}

\section{Table 1}

\begin{tabular}{|l|l|l|}
\hline Sampling region & Freq. & Percent \\
\hline Tbilisi & 9 & 40.91 \\
\hline Kvemo Kartli & 0 & 0.00 \\
\hline West & 2 & 9,09 \\
\hline Kakheti & 2 & 9,09 \\
\hline Mtskheta-Mtianeti and Shida Kartli & 4 & 18.18 \\
\hline Coastline & 5 & 22.73 \\
\hline Total & 22 & 100.00 \\
\hline
\end{tabular}

In the analysis, we examine the relationship between export intensity (the percentage of exports in total sales) and different types of innovation. The analysis includes four indicators of innovation activity as dummy variables: 1) the firm introduced product and service innovation, 2) the firm introduced new production/supply methods over last 3 years; 3) firms introduced new organisational/management practices or structures over last 3 years; 4) firms introduced new marketing methods over last 3 years; 5) firms improved business process; 6 ) firms is engaged in the R\&D activities.

\section{Definitions and Descriptive of variables}

\section{Table 2}

\begin{tabular}{|l|l|l|l|l|}
\hline Variable name & Description & Obs. & Mean & Std. Dev. \\
\hline Export intensity & Indirect exports as a \% of total annual sales & 360 & 1.161111 & 8.005335 \\
\hline Export intensity & Direct exports as a \% of total annual sales & 360 & 2,65 & 14.09813 \\
\hline \multirow{2}{*}{$\begin{array}{l}\text { Product/service } \\
\text { Innovation }\end{array}$} & New products/services introduced over last 3 yrs & 360 & 1,90 & .3004175 \\
\cline { 2 - 5 } & $\begin{array}{l}\text { New products/services new to one of the establishment's } \\
\text { markets }\end{array}$ & 36 & 1.138889 & .3507362 \\
\hline \multirow{5}{*}{ Process innovation } & New production/supply methods introduced over last 3 year & 360 & 1.841667 & .8639725 \\
\cline { 2 - 5 } & $\begin{array}{l}\text { New organizational/management practices or structures } \\
\text { introduced over last }\end{array}$ & 360 & 1.902778 & .6280296 \\
\cline { 2 - 5 } & New marketing methods introduced over last 3 yrs & 360 & 1.791667 & 1.179414 \\
\hline
\end{tabular}




\begin{tabular}{|l|l|l|l|l|} 
& Business process improvements & 36 & 01.2 sol & .5070926 \\
\hline Business skill & Business skills improvements & 36 & 1.277778 & .4542568 \\
\hline R\&D activities & Spending on R\&D & 360 & 1,95 & .2182483 \\
\hline Skilled worker & & 113 & 34.07965 & 97.12319 \\
\hline Unskilled worker & & 113 & 6.893805 & 16.50669 \\
\hline Domestic firms & owned by private domestic individuals & 360 & 95.85556 & 17.83525 \\
\hline Foreign firms & owned by private foreign individuals & 360 & 3.680556 & 16.80432 \\
\hline performance & Total annual sales 3 yrs ago & 360 & 1771265 & 9481081 \\
\hline firms size & $\begin{array}{l}\text { At the end of fiscal year [insert last complete fiscal year], how } \\
\text { many permanent, full-time employees did this establishment } \\
\text { employ? Please include all employees and managers }\end{array}$ & 360 & 34.48056 & 82.58508 \\
\hline Capital intensity & Capacity Utilization in last fiscal year & 113 & 51.33628 & 28.667 \\
\hline Age & In what year did this establishment begin operations & 360 & 2001.772 & 14.02041 \\
\hline
\end{tabular}

We also include a range of control variables. One such additional variable is firm size. Firm size is expected to have a positive relationship with export intensity as larger firms have more ability to bear the costs of foreign market entry. Higher capital intensity (fixed assets per employee) of a firm is likely to make it more export competitive as capital goods may embody improved technology, while capital intensive production is consistent with the comparative advantage of developed countries (Belderbos R., 1998). Firm age may have a complex relationship with exporting (Arnold, 2005) (Wagner, 2007), with young inexperienced firms less likely to export, but with older firms perhaps suffering from less dynamism and a „liability of adolescence” (Hannan MT., 1998). The analysis also takes into account activities of domestic and foreign firms (owned by private domestic and foreign individuals) skilled and unskilled workers (At the end of fiscal year how many permanent, full-time employees were: Skilled and unskilled production workers). Table 2 includes the description, mean and standard deviation for each variable per. The average export intensity for the sample is 1,16 (Indirect exports as a \% of total annual sales) and 2,65 (Direct exports as a \% of total annual sales).

\section{Average characteristics of firms with and without innovation}

Table 3

\begin{tabular}{|c|c|c|c|c|c|c|c|c|}
\hline \multirow{3}{*}{ Variables } & \multicolumn{2}{|c|}{$\begin{array}{l}\text { Product/service } \\
\text { Innovation }\end{array}$} & \multicolumn{2}{|c|}{$\begin{array}{l}\text { New } \\
\text { production/supply } \\
\text { methods }\end{array}$} & \multicolumn{2}{|c|}{$\begin{array}{l}\text { New } \\
\text { organisational/ma } \\
\text { nagement } \\
\text { practices }\end{array}$} & \multicolumn{2}{|c|}{$\begin{array}{l}\text { Business } \\
\text { process } \\
\text { improvements }\end{array}$} \\
\hline & no & yes & no & yes & no & yes & no & yes \\
\hline & $\begin{array}{l}\text { Mea } \\
n\end{array}$ & Mean & \multicolumn{2}{|l|}{ Mean } & \multicolumn{2}{|l|}{ Mean } & \multicolumn{2}{|l|}{ Mean } \\
\hline Export intensity (indirect export) & 0,7 & 4,6 & 1,65 & 2,11 & 1,24 & 0 & 5,2 & 7,5 \\
\hline Export intensity (direct export) & 2,33 & 5,4 & 2,36 & 5,42 & 2,29 & 7,7 & 0,94 & 10 \\
\hline firms size & 2,23 & 84,4 & 27,85 & 97,22 & 27 & 128 & 61 & 82 \\
\hline Capital intensity & $\begin{array}{l}50,3 \\
3\end{array}$ & 55,76 & 50,26 & 57,26 & 51,58 & 47,33 & 44,42 & 44,3 \\
\hline Skilled worker & $\begin{array}{l}23,7 \\
3\end{array}$ & 79,5 & 23 & 75 & 22 & 129 & 27,5 & 33,5 \\
\hline Unskilled worker & 5,39 & 13,42 & 4,48 & 12,65 & 5 & 19 & 13,28 & 6,7 \\
\hline R\&D spending & & & 1,98 & 1,68 & 1,98 & 1,5 & 1,88 & 1,55 \\
\hline
\end{tabular}

We differentiate variable means by innovation type (table 3). Firms that introduced both products and process innovation show the highest export intensities. Firms focusing on product innovations have large number skilled worker, but smaller on average than firms engaged in business process improvement. Non-innovating firms are on average, smaller, less productive then innovating firm but not in terms of capital intensity.

Table 4 shows estimation results for a probit equation indicating that R\&D has a strong positive association with Export activities. For example, a one percentage point increase in R\&D spending increases the probability of Export activities by 
$0.63 \%$. Skilled worker and firms's age has no effect on export activities. Firms which are involved in product/service innovation have a $20 \%$ greater chance to be involved in export activities. Capital intensity and firm's size also affect export activities by $0,6 \%$ and $0,8 \%$ respectively.

\section{Determinants of Export Activities}

\section{Table 4}

\begin{tabular}{|l|l|l|}
\hline Probit regression & \multicolumn{2}{|l|}{ Direct exports as a \% of total annual sales } \\
\hline & Coef. & Std, Err. \\
\hline Skilled worker & $-0,0080039$ & 0,0052721 \\
\hline Unskilled worker & 0,0071686 & 0,0120938 \\
\hline Capital intensity & 0,0067514 & 0,0070434 \\
\hline firms size & 0,0089679 & 0,0045944 \\
\hline Age & $-0,0303188$ & 0,0128645 \\
\hline R\&D activities & 0,6340462 & 0,7883677 \\
\hline Product/service Innovation & 0,2093716 & 0,4895117 \\
\hline Log likelihood = & $-34,252988$ & \\
\hline Number of obs $=$ & 113 & \\
\hline
\end{tabular}

\section{Summary}

Innovations make one of the key factors of company's export competitiveness. The research suggests that low innovation level occurring in a company is important for the development of the company's exports and has become the reason for its decision not to become involved in exporting activities. According to the research only 5-10 percent of Georgian firms are engaged in some type of innovation process. Companies should implement innovation if they want to become exporter.

Results highlight that the introduction of innovations, and in particular product innovation, is an important driver of export intensity and export growth. Firms that introduce only process innovations also export more. Our results emphasize the important role of innovation as a major driver of export performance of Georgian firms. Research shows that new product introduction and modernization are one of the important factors for export competitiveness. The implication of the findings will be important for policy makers to develop strategy for stimulating persistent innovation efforts, and in particular R\&D activities and product innovation, are essential to stimulate export competitiveness and may serve as one of the most effective export promotion policies.

\section{References}

[1] Arnold, J. M. (2005). Export behavior and firm productivity in German manufacturing. Weltwirtschaftliches Archiv, pp. $219-243$.

[2] Becker, S. e. (2007). Endogenous Product Versus Process Innovation and a Firm's Propensity to Export. . CESIFO Working Paper No. 1906.

[3] Belderbos R., \&. S. (1998). Tariff jumping DFI and export substitution:Japanese electronics firms in Europe . International Journal of Industrial Organization., pp.601-638.

[4] Cassiman, B. e.-R. (2007). Product innovation and exports: evidence from Spanish manufacturing . IESE working paper. Mimeo.

[5] Dollar, D. (1986). Technological Innovations, Capital Mobility, and the Product Cycle in North-South Trade. American Economic Review,, pp. 177-190.

[6] Fagerberg, J. (1996). Technology and competitiveness . Economic Jurnal, pp.355-377.

[7] Fagerberg, J. (1996). Technology and Competitiveness. Oxford Reveiw of Economic Policy., pp.39-51.

[8] GII. (2016). Global Innovation Index. 
[9] Greenhalgh, C. T. (1994). Innovation and Export Volumes and Prices--A Disaggregated Study. Oxford Economic Papers, pp. 102-135.

[10] Grossman, G. a. (1991a). Trade, knowledge spillovers, and growth. European Economic Review(35), 517-526.

[11] Hannan MT. (1998). Rethinking age dependence in organizational mortality: logical formalizations. American Journal of Sociology, pp. 126-164.

[12] Hirsch \& Bijaoui. (1985). R\&D intensity and export performance: a micro view. Weltwirtschaftliches Archiv,, pp. 138-251.

[13] Hobday, M. (1995). East Asian Latecomer Firms: Learning the Technology of Electronics. World Development, pp. 1171-1193.

[14] Krugman, P. (1979). A model of innovation, technology transfer and world distribution of income. Jurnal of Political Economy, pp.253-266.

[15] Kumar, N. a. (1994). Technology, firm size and Export Behaviour in Developing Countries. The case of Indian Enterprise. Jurnal of Development studies, pp. 289-302. .

[16] Lefebvre, E. L. (1998). R\&D related capabilities as determinants of export performance. Small Business Economics, pp.365-377.

[17] Melitz, M. (2003). he impact of trade on intra-industry reallocations and aggregate industry productivity,. Econometrica, , 71, 1695-1725.

[18] Pillania R. K. (2009). Competitiveness and emerging markets. Business Strategy Series, Vol. 10 Iss: 2, pp. pp. 90-95.

[19] Porter, M. E. (1980). Competitive Strategy: Techniques for Analyzing Industries and Companies.

[20] Posner, M. (1961). International Trade and Technological Change. . Oxford Economic Papers. , pp. 11-37. .

[21] Posner, M. V. (1961). International Trade and Technical Change. Oxford Economic Papers, 323-341.

[22] Raluca O. (2011). The journey to competitiveness: EU speeding up on the road paved with knowledge and innovation. Economic Science Series, Vol. 20 I(ssue 1), pp. pp.118-124.

[23] Romer, P. M. (1990). Endogenous Technological Change. Journal of Political Economy, pp. 71-102.

[24] Schwab K. (2012). The Global Competitiveness Report. World Economic Forum. Geneva.

[25] Sterlacchini. (1999). Do innovative activities matter to small firms in non-R\&D-intensive industries? An application to export performance. Research Policy, pp. 819-832. .

[26] Tidd, J. \&. (2009). Managing Innovation, Integrating Technological, Market and Organizational Change. pp. 2425.

[27] Vernon, R. (1966). International Investment and International Trade in the Product Cycle. Quarterly Review of Economics, pp. 190-207.

[28] Wagner, J. (2007). Exports and Productivity: A Survey of the Evidence from Firm-level Data. The World Economy,, vol. 30(1),, pp. 60-82, 01.

[29] World Bank. (2013). Enterprise Surveys. World Bank Group.

[30] World Economic Forum. (2017). The Global Competitiveness Report 2016-2017.

[31] Young, A. (1991). Learning by Doing and the Dynamic Effects of International Trade. Quarterly Journal of Economics, pp. 369-405. 